\title{
Displacement a pojem tradiční lidové kultury
}

\author{
Petr Kouril
}

Způsobů, jak vztáhnout partikulární historii národního státu k univerzální Historii, je možné najít mnoho. Vedle symbolů schopných evokovat sdílenou dějinnou pamět' tu stojí i neživí svědkové minulých dob - materiální kultura $\mathrm{v}$ podobě času odolávajících předmětných důkazů tvořivosti předků; hradů, domů, zbraní, hrnců či písemností. Vedle těchto takříkajíc mrtvých svědků minulosti však lze najít i svědky docela živé. Je to především oblast nehmotné kultury, a také kultury, jejímž nositelem není papír, kámen či pergamen, nýbrž samotný aktér. Expresivní formy tradiční lidové kultury, zvané donedávna s oblibou folklór, jsou zhusta považovány za důkaz platnosti státní historie, totiž existence historického lidu, jenž nejen, že existoval v minulosti, nýbrž existuje i nyní.

Folklorizaci lidu lze řadit mezi jedno ze sebelegitimačních narativ národního státu. Je to však legitimizace paradoxní. Při vší úctě chované k ,prostotě“ lidového člověka se nabízí otázka, jak může obraz zemědělce shrbeného nad svou půdou reprodukovat dojem národní hrdosti a emancipace? Vždyt' onen proces „folklorizace“ s sebou kromě estetizace nese i značnou nálož primitivity. Je to jen modernizační ústupek zbytku zemědělské populace? Domnívám se, že nikoliv. Existence autentické lidové kultury dává národnímu státu potenciál vyprávět vlastní i velkou historii uvnitř „svých hranic“, čerpat z vlastních symbolických zdrojů a neplýtvat jimi, ale zároveň indexovat „zákon historie“ na nejobecnější úrovni. Zmíněný paradox tradiční lidové kultury je vlastně paradoxem historického narativa lidu-státu samotného - být současně konkrétní $\mathrm{v}$ historické př́tomnosti i obecný ve věčnosti.

Tradiční lidová kultura tak vytváři časovou distanci mezi tradičním a moderním řádem. Kromě toho, že je živým a přítomným důkazem a definičním znakem, má ještě jeden podstatný rys. Lidová kultura je kulturou takříkajíc „nízkou“. Vedle historické a kulturní horizontály ji lze vymezit i vzhledem k sociální vertikále. Vzniklé pole již není jen pouhou odlišností, nýbrž zprítomňuje řád s mocenským „dole“ a „,nahoře“. Tato skutečnost se pak přenáší i na onu úroveň velké historie - vzniká představa řádu světa v němž národy vládnou „pronárodům“. Důkaz vlastního, historicky překonaného - folklorizovaného - primitivizmu zakládá nárok na ovládání a podmanění primitivizmu Druhého či Jiného. Na druhou stranu tento „důkaz“ udržuje nostalgickou touhu moderního člověka po prostém a primitivním, činí z Druhého objekt obdivu a uctívání.

Rozdíl mezi primitivizmem tradiční lidové kultury a kultury Druhého lze podle mne dobře pochopit na základě pojmu displacement. Pokud lze displacement Druhého na první pohled vnímat jako vymístění či vykázání z historie, pak při bližším pohledu se zdá být zásadní jeho vymístění z přítomnosti. Folklorizace je $\mathrm{v}$ jistém smyslu řešením paradoxního nároku na historičnost i věčné trvání a zaručuje tradiční lidové kultuře místo v emancipované kultuře národní. Prakticky každá jiná kultura zakládající si nárok na původnost, nespojená

Sociálni studia. Fakulta sociálních studií Masarykovy univerzity v Brně, 2/2004. S. 43-56. ISSN 1214-813X. 
však s emancipovanou kulturou národa, je odsouzena do role kultury primitivního Druhého. Historická narace se rázem mění na naraci př́itomnosti, narace časová se transformuje v naraci prostorovou.

V následujícím textu se nejdříve zaměřím na pojem displacementu, přičemž se pokusím uchopit vymístění, evokující přesun prostorem, jako přesun symbolický. Tím, co se pohybuje, jsou pak identity: ačkoli se jedny jeví jako stabilní (zakořeněné) a druhé v pohybu (migrující), $\mathrm{k}$ přesunu v podstatě dochází u obou. Přesun tedy není tím, co by mezi nimi vytvářelo rozdíl. Tradiční lidová kultura, postavená vedle „,vykořeněné“ kultury migrantů, může být př́íkladem takovéto zdánlivé nehybnosti - $\mathrm{i}$ ona se ve skutečnosti neustále mění a obnovuje. V další části textu se zaměřím na př́klad kulturní politiky českého státu. Na dokumentech Strategie účinnějš́ státni podpory kultury a Koncepce účinnějši péče o tradiční lidovou kulturu v Č́R stručně rozeberu vztah současného českého státu $\mathrm{k}$ tradiční lidové kultuře. Poté krátce prolistuji folkloristickou literaturu, která se snaží uchopit svůj vývoj v reflexi vývoje předmětu zájmu svého zkoumání: folklóru. Celou historii této disciplíny lze přitom chápat jako dějiny hledání autenticity (Bendix 1997). A v konceptu autenticity se opět setkává tradiční lidový člověk se svým primitivním kulturním protějškem, s oním „Druhým“. Oba jsou mlčenlivými aktéry narativa modernizace.

\section{Displacement jako strukturální událost}

Displacement lze v první řadě chápat jako pojem (dis)lokační, tj. pojem spojený s určitým pře- či umístěním v prostoru. $V$ druhém čtení pak najevo vychází i další „existenciální“ dimenze, a tou je pojem času, konvence zaznamenávající průběh a vůbec možnost změny. Stejně jako s prostorem a časem je pak pojem displacement $\mathrm{z}$ mého hlediska nevyhnutelně spojen s určitou identitou. A je to právě identita, která si především zasluhuje pozornost. Jednoduše řečeno, jde o to, co se s ní děje, je-li přesazena $\mathrm{z}$ jedněch „,prostorových“ podmínek do druhých. Vztah identity a prostoru je základním vztahem displacementu, tak jako se stolní hra začíná postavením figur na herní plochu. Tato prvotní konfigurace však mnoho neřekne, stejně jako by bez významu bylo prostě konstatovat „událost přesunu“. Na nastíněném př́kladu se vynořuje rozpor mezi strukturálním a událostním pojetím skutečnosti. Jak lze tento rozpor překonat?

V tomto textu se pokusím nabídnout jedno řešení, či snad lstivý teoretický úskok. Vychází z problematizace pojmu prostoru prostřednictvím jeho „symbolizace“. Čas, zbaven vztahu $\mathrm{k}$,fyzické“ podstatě prostoru, je transponován do jeho symbolických struktur. Přestává plynout, neztrácí však schopnost vypovídat o změně. Událost v čase je nyní událostí strukturální. Důležitým pojmem se stává „hranice“, která se ve své symbolické podobě stává identifikátorem změny. Tato symbolická hranice je vlastně jakousi strukturální podmínkou - dojde-li k jejímu naplnění, dojde i k posunu či inovaci významu. A to jak na straně aktéra změny, tak na straně struktury. Zvýznamněn je jak akt změny, tak rozlišení prostoru na prostor „před“ a „potom“, tj. historizující narativní potenciál, a nakonec i sama dělící hranice.

Zdůrazněním symbolické strukturace prostoru bych nerad popřel platnost jeho fyzičnosti, stejně jako bych nerad vyvolal dojem demonstrace verbální artistiky. Relativizace fyzičnosti prostoru má mimo svůj teoretický účel i praktické důsledky. Pokouší se jednoduše ukázat, že 
fyzický referent nelze zaměňovat za významy, které může nést. Zároveň však platnost „fyzičnosti“" prostoru nezavrhuje, nebot' ona sama nese jistý význam. Ve smyslu Barthesova (2004) dvoustupňového systému označování je fyzičnost součástí společenské mytologie, respektive dominantního diskurzu. Koneckonců i sám pojem prostoru je ve svém nejpartikulárnějším uplatnění vždy už abstrakcí a transcendencí. Zařadím-li objekt do prostoru, vidím jej nejen v novém významovém obklopení či kontextu, ale i obohacený pojmenováním prostoru, které se zde uplatňuje jako paradigma či hyperonymum.

Prostor je tedy vždy především metaforou, spíše procesem přenášení významu, než statickou, nominální kategorií. Symbolický prostor je pak Prostorem par excellence. Fyzický prostor není skutečnější - „fyzické“ je tu spíše př́ívlastkem, metaforickým přenesením významu z paradigmatu přirozena a stability, strukturovaného organizací společenské moci. Metaforičnost však zároveň činí pojem prostoru poněkud rozmlženým a vágním, když mu, ve schopnosti pojmout cokoliv, odebírá možnost vypovídat. Pokud bychom setrvali pouze u metafor vytvořených pro účel analýzy, pak by tato ztráta významu byla jistě nevyhnutelná. Proto nelze nárok na platnost, nikoliv však na pravdivost, fyzičnosti prostoru jednoduše pominout, je nutné ji vidět nikoliv jako intelektuální, nýbrž jako sociální konstrukt.

Metaforický potenciál pojmu prostoru bere smysl pokusu o výčet všech jeho možných existujících podob či jejich hierarchizací v podobě nominálních kategorií. Arbitrárnost a zároveň společenská platnost fyzična však umožňuje nabídnout několik př́kladů. Za prostor, který se jeví jako „ohraničenost“ substanciální povahy, lze považovat lidské tělo, území státu, prírodu jako ontologický prostor prrirozena, ale koneckonců i entity se zcela jinou kvalitou hmatatelnosti, jako je společnost jako národní sociální prostor, mysl jako duševní prostor, etnikum jako kulturní prostor a nakonec i samotná identita jako prostor kolektivního i individuálního bytí.

Zdá se, že diskurzivní zakotvení fyzičnosti prostoru lze nahlédnout právě ve strukturální události, kterou můžeme nazvat symbolickým displacementem. Přidržme se obvyklých expertních ukázek vymístěných jednotlivců či kolektivit, které čerpají analytické možnosti z kritiky paradigmatu „Jinakosti““, a spojují vymístěnost zkoumaných identit s jejich fyzickým, teritoriálním a v podstatě plošným přemístěním - řeč je o uprchlících, imigrantech, exulantech, vyhoštěných atp. Vysvětlování ,jinakosti“ migrantů jejich teritoriálním přesunem je stejně substancializující jako kritizovaná konstrukce jinakosti. Pouhý fyzický přesun není schopen spustit narativa jinakosti. Hledisko prostorového přesunu, tj. pohybu tělesného prostoru prostorem teritoriálním, skrývá další předpoklady, které k plošnému přesunu přidávají i vertikální vektor. Přesun je tak nakonec spíše transformací jedné mocenské/symbolické vertikality do vertikality druhé. Migrant se do inferiorní pozice nedostává proto, že se geograficky přesune (přiblíží se). V inferiorní pozici se v očích „přijímajícího“ a interpretujícího nachází již před svým přesunem a akt migrace je jen horizontální symbolickou transformací jedné vertikály v druhou. Př́kladem může být transformace vertikály (vzdálené) civilizovanosti ve vertikálu (zde př́tomného) sociálního postavení.

Onen transformativní prvek, symbolickou podmínku, lze identifikovat ve skutečné fyzické, státní hranici, jejíž překročení je aktem signifikace, a to, jak již bylo řečeno, nejen aktéra, nýbrž celé strukturální i dějové situace, připravující nástroje pro určitou preferovanou interpretaci. Symbolický akt překročení zvýznamňuje prostor „opuštěného“ i „dosaženého“ státu, 
načrtává mezinárodní prostor, dává význam samotné hranici, legitimuje ji a zvýznamňuje také způsob jejího překročení. Vykresluje prostor, který je členěn nejen plošně, ale i svisle, kde moc teritoriality se prolíná s mocí sociální, kde výška hraniční závory se mění s tím, kdo ji překračuje.

Př́klad uprchlíků či běženců vnáší do sociálních věd téma, které by bylo možno nazvat „problém displacementu“. V čem spočívá? Jednak na něj lze nahlížet jako na „vytrhování identity z původního prostoru“. V tomto „zemědělsko-rostlinářském“ diskurzu, kde teritorium vystupuje jako obdělávaná půda, můžeme hovořit o „vykořenění“. Druhou možností je problematiku poměru identity k prostoru vidět jako „zasazování identity do prostoru nového“, či „zakořenění“. V obou př́padech odkazuje existence migrace na jisté symbolické uspořádání př́tomné sociální skutečnosti, tj. na více než jen analytické vydělování se identity z prostoru. Může se nyní zdát, že veškerá tragika tématu spočívá právě v tomto odcizení. Podle mého názoru však displacement nemusí být jen narativem krize kořenového systému - stejně dobře vyhovuje př́iběhu zcela opačnému, avšak komplementárnímu. Je to modernizační nacionalistické narativum vzniku státu, indexující symbolický prostor pomocí události emancipace národní identity. Tento zlom lze vnímat právě jako oddělení prostoru a identity, komplementární se zmíněným „problematickým“ zlomem migračním.

Oba př́ípady mají společné ono oddělení, k němuž dochází za současného uchování si vazby. Rozdíl mezi nimi spočívá ve směru determinace. S odkazem na P. Bourdieu (1998) lze prohlásit, že identita je jednou strukturou strukturující, podruhé strukturou strukturovanou; s prostorem je tomu $\mathrm{v}$ opačném pořadí. $\mathrm{V}$ prrípadě emancipující modernizace se prostor proměňuje ve sféru přirozena a stává se definičním komplementem emancipované identity, osvobozeného rozumu.

Součástí prostoru přirozena je i tradiční lidová kultura. Odkazuje na „původní stav“, prezentuje se zejména jako prostá zemědělská a řemeslnická kultura, stejně jako se vymezuje vičč současnosti. Hovoří o vztahu $\mathrm{k}$ současnosti a budoucnosti, zakládá prŕběh patrimonialismu, dědičného, pokrevního vztahu k půdě. Modernizovaný způsob vyprávění o univerzálním dědičném nároku se skrze displacement stává i součástí diskurzu teritoriální migrace. Tradiční „kulturní dědictví“ je zakořeněno v půdě otců a je povinností potomků pečovat o ně a nedrobit je.

\section{Tradice a proměna}

Tradiční lidová kultura aspiruje na společenskou integrační funkci, není však nutně spojena s „tradicionalismem“. Její schopnost „přežít“ a neztratit svoji stále zpochybňovanou autenticitu hovoří o neslábnoucích schopnostech modernizačních narativ. Jinými slovy, tradiční lidová kultura je autentická natolik, nakolik je moderní. Neustálá proměna moderní společnosti si vynucuje i transformaci tradice a folklóru, a to prostřednictvím proměny definičních polarit. Jestliže významová hodnota folklóru původně vyrůstala z distinkce venkov/město, nyní můžeme, ačkoliv přetrvává i onen původní rozdíl, hovořit spíše o distinkci soukromé/ /veřejné, a rozdíl tak vidět $\mathrm{v}$ míře privatizace folklóru.

Neznamená to však, že by se folklór uzavíral za dveře bytů a domů. Spíše naopak: folklórní projev je spojen se svou veřejnou prezentací. Není však běžnou součástí života veřejnosti, je vázán na určitou specifickou událost slavnosti či představení. Je však také neoddě- 
litelný (až na výjimky) od soukromého volného času, když je chápán jako jedna z možných „zájmových aktivit“. Lidé praktikující folklór, střežící tradice a „prostou krásu“ lidového tance, písně a jiných projevů, jsou z drtivé většiny amatéři - jsou to lidé, pro které je folklór doslova „srdeční záležitostí“. Takováto forma zájmové aktivity se realizuje v podobě různých spolků a sdružení, což folklóru dodává na zvláštní „objektivní dostupnosti“ smyslu a autenticity. Nostalgie ke Gemeinschaft se tu uskutečňuje prostřednictvím drobných forem sdružování, ve skupinách o menším počtu lidí. Organizovanost folklóru do větších celků, do národních sdružení, pak dokáže tomuto jednotlivému soukromému společenství zprostředkovat smysl nejširší a univerzální.

Je tu však především stát, který, at' už svými př́tomnými či minulými aktivitami, tuto soukromou zájmovou aktivitu strukturuje. Vztah k folklóru tak může být př́ikladem propojení státního smyslu se smyslem individuálním, propojení soukromé aktivity se státním myšlením i cítěním (Bourdieu 1998). Jednotlivci provozující folklór si však nekladou za cíl legitimizovat struktury národního státu. V lidovém projevu patrně hledají věci mimo kalkul a rozum, návrat ke kořenům, $\mathrm{k}$ hodnotám a prostotě. Vyvoláváním tradice tak nepř́mo pomáhají udržovat ,živý odkaz předků“ a národa vůbec. Tento legitimizační vztah však není, jak již bylo naznačeno, „výhodný“ pouze jednostranně, jde tu o jakousi formu státně-soukromé symbiózy. Stát dodává folklórní činnosti, rovněž patrně nezáměrně, ,nadindividuální smysl“ a univerzalizující zasazení.

Folklór je způsob vztahu k tradici. Nutno říci, že jde o způsob aktivní, a to hned ve dvou ohledech. Za prvé, folklór je spíše než stavem mysli, názorem či věděním, určitou praxí - zpěvem, tancem apod. Za druhé je vztah folklóru k tradici aktivní v tom smyslu, že tento se pružně přizpůsobuje svým legitimačním potřebám, svému modernímu hladu po univerzálnu. V tomto ohledu je zjevné, že je více než od udržování určité podoby tradice odvislý od své schopnosti indexovat univerzálno. Dokud bude stát vlastníkem monopolu na symbolický kapitál, bude tradiční lidová kultura vázaná na jeho legitimizační potřeby. Bude se jim přizpůsobovat a těžit z nich. Pokud však, jak naznačují někteří autoři v diskusi o globalizaci, stát o svůj monopol přijde, nemusí se př́znivci tradice zániku folklóru obávat. Jestliže zformování se státu $\mathrm{v}$ prostředí industriálního kapitalismu dalo vzniknout folklóru $\mathrm{v}$ jeho současné podobě, dokázalo mu dát prostor, organizaci, expertní potenciál a také jednotlivce transgregující smysl, pak změna státní organizace či rozpuštění se státu v širších strukturách může znovu ustavit diskusi o autenticitě konceptu tradiční lidové kultury; vést $\mathrm{k}$ jejímu přizpůsobení se oněm novým podmínkám.

Nový kontext existence folklóru vytváří např́klad trend evropské regionalizace a vůbec podpora vzniku nových forem lokálního patriotismu. Zakrýváním státních hranic mohou na mapách Evropy do budoucna zanikat tradiční folklórní rajonizace, a naopak vznikat nejrůznější přeshraniční tradičně kulturní celky, znovuobjevené pozůstatky dřívější státní organizace, nové regionální historie. Výzvou a novým aktualizačním kontextem se pro folklór stává také expertní a postupně i administrativní diskurz etnicity a etnik. Nástup tohoto diskurzu lze sledovat $\mathrm{v}$ proměně expertního národopisného i etnografického slovníku. Etnografie, dř́ve zaměřená na exotické domorodce, nyní expanduje i do původní sféry folklóru, folkloristika se zase rozšiřuje i na dř́ve neautentické území města. Kromě tohoto posunu lze sledovat i změnu v soukromě provozovaném folklóru. Projevy tradiční lidové kultury jsou etnicizovány na poli 
populární hudby ve formě etnomusic či worldmusic. Etnicizace folklóru nabízí nové způsoby univerzalizace.

Stejným způsobem jako folklórní hnutí hledá své legitimizační zdroje v obnově tradice, hledá je i stát. Mohutné propojení „spontánni'“ folklórní aktivity s funkcionálním hlediskem státu není věčné a samonosné - i stát musí vyvíjet aktivitu, kterou si tradici v podobě folklorního hnutí připoutá $\mathrm{k}$ tělu a udrží si vliv na jeho podobu. Tuto aktivitu lze vystopovat v podobě kulturní politiky státu. Stát věnuje prostředky amatérskému i expertnímu vytváření a udržování tradice a v podstatě otevřeně vnímá význam, který může tato symbolická aktivita mít pro integritu a legitimitu organizačního těla. Hovoří o funkcích tradiční lidové kultury, dívá se ni okem ekonoma i terapeuta, na druhou stranu se však snaží neporušit auru autenticity a posvátnosti. Stát se záměrnou činností snaží udržet autentickou kulturu „svého“ lidu a odkrývá tak jeden ze svých legitimizačních mechanismů. Nemusí zde odhalovat „skryté významy“, abychom viděli, jak se snaží koncentrovat a investovat kapitál přirozena, který spolu s potenciálem donucovací síly tvoří dvě strany mince státní moci.

\section{Kulturní politika ČR a ochrana tradiční lidové kultury}

Následující text chce ukázat, jak je záměrnou politikou udržováno pole, které je paradoxně definováno jako produkt nezáměrné a nekalkulované činnosti, jako „pole autenticity“. Interpretací Koncepce účinnějši péče o tradiční lidovou kulturu v České republice chci poukázat na to, že schopnost reprodukce (aktualizace) tohoto pole vychází z narativního potenciálu výše zmíněného konceptu displacementu, tak jak existuje v podmínkách modernity. Text Koncepce k aktualizaci vhodně využívá reflexi př́tomné společenské proměny, zde zastoupené př́padem eroze socialistických institucí tradiční kultury. Tato „společenská změna“, ke které došlo po roce 1990, podporovaná navíc vidinou změny nadcházející, totiž vstupem do EU, je ve zmíněném právním textu př́iležitostí spustit narativum národního státu, založené na představě autentické lidové identity.

V lednu 2001 vydává vláda ČR Usneseni o aktualizaci Strategie účinnějši státni podpory kultury, pracovně nazývané „kulturní politika“, jenž by mělo být programem podpory „kultury" do roku 2005.

Věřím [ministr kultury, pozn. PK], že význam tohoto dokumentu [kulturní politiky] vzrostl v souvislosti se zřízením krajů a ještě poroste při dalších přesunech zodpovědnosti za kvalitu kulturního prostředí našich životů ze státní správy na samosprávu. Doufám, že v Kulturní politice najdete odpovědi na své otázky, týkající se kultury, najdete zde inspiraci pro svou činnost v kterékoli sfére občanské společnosti. Pak se podaří naplnit smysl Kulturní politiky, jejímž cílem je dále rozvíjet svobodný, bohatý, pestrý a zajímavý kulturní život nás, všech občanů této krásné země, i našich hostů, a, jak nás zavazuje tradice dobrého jména české kultury, snažit se přispívat do pokladnice lidstva.

(Kulturní politika 2001: 2)

Definice pojmu kultura je provedena funkcionálně. Funkčnost kultury tak zároveň zdůvodňuje potřebu systematické péče o ni, potřebu politiky ochrany. Dokument uvádí šest funkcí kultury, které lze interpretovat jako součásti tř́i obecnějších funkcí - státně-symbolické, ekonomické a sociální. Do první skupiny lze zařadit tyto funkce kultury: integrace celku, výchovná funkce ${ }^{1}$ a distinktivně-reprezentační funkce². Druhou významnou obecnou funkcí 
je funkce ekonomická - kultura vytváří přímé prostředky z daňových výnosů a tzv. kulturního průmyslu, ${ }^{3}$ ale také působí nepřímo tím, ,že vytváří podmínky pro vznik príijmů státního i komunálních rozpočtů např. daňovými výnosy tzv. kulturního turismu, jehož významným motivem je naše kulturní dědictví. Součástí aktivní ekonomické funkce kultury je i to, že nabízí pracovní př́ležitosti pro řadu občanư“ (Kulturni politika 2001: 4).

Poslední skupinou funkcí je skupina sociální. Do ní lze zařadit sociálně-motivační funkci kultury, odkazující ke smysluplné náplni volného času jako prevenci proti sociální patologii. A dále také funkci sociálně-solidarizační, vedoucí k prevenci rasové nesnášenlivosti a integraci národnostních menšin a zdravotně, či jinak postižených, u nichž lze též hovořit o jakési „terapeutické funkci“.

V tomto pojetí vystupuje kultura $\mathrm{v}$ podobě státního bohatství, které zdědila z minulosti a o něž je nutno pečovat a zhodnocovat je. Tato vlastnická metafora se nevztahuje jen na oblast peněžní ekonomie, ale i na oblast určité sociální a symbolické ekonomie - ekonomie státní moci. Nehmotné dědictví kultury zde představuje způsob, jak udržet integritu státu, vystavovanou nepř́znivým historickým okolnostem. Udržení integrity pak v tomto kontextu není jen zájmem vlastního státu, nýbrž zájmem na udržení univerzálního řádu - je přispíváním do ,pokladnice lidstva“.

Důležitou součástí péče o současnou státní kulturu je i péče o tradiční kulturu (tzv. „kulturní dědictví"), ke které je připojen atribut „lidová“.

Významnou součástí materiálního i duchovního bohatství České republiky je její kulturní dědictví. Jeho prostřednictvím se z generace na generaci přenášejí hodnoty, vytvářené po celá staletí. Je základem kulturní identity, zdrojem kulturní rozmanitosti a vzdělanosti, přispívá ke kultivovanosti občanů, je důležitým fenoménem ve využivání volného času (v tomto směru může sloužit jako nástroj proti sociálně patologickým jevům) (Koncepce 2003: 3).

Koncepce zdůvodňuje potřebu ochrany nejen $\mathrm{z}$ důvodu státního či společenského, a také ekonomického zájmu, ale také z důvodu podpory základních lidských práv, v nichž je stanoveno, že stát musí jednotlivci zajistit př́ístup ke kulturnímu bohatství. Stát takto předpokládá a chrání zájem o lidovou kulturu. Nástroji ochrany je pak identifikace, dokumentace, ochrana a využití a „p̌redávání dalším generacím“.

Zvláštní rys české tradiční lidové kultury vyjadřuje fakt, konstatovaný ve formulaci ,projevy tradiční lidové kultury se dochovaly v životě současné společnosti nerovnoměrně v různých regionech i společenských vrstvách“. Tato „nerovnoměrnost“ může být obzvlášt” zajímavou indicií při zkoumání „povahy“ české lidové kultury. Část nepokrytého území lze chápat jako důsledek procesů industrializace a urbanizace. Především př́hraniční části však také mohou odkazovat na někdejší existenci „druhého lidu“ - českých Němců - po jejichž odchodu/odsunu vznikla jistá symbolická díra, uchovávaná v podobě odkazu na „nerovnoměrné dochování se“.

Tradiční lidovou kulturu lze v textu Koncepce identifikovat podle těchto induktivních rysů: nositele, způsobu reprodukce, projevů a nakonec lokálního vymezení. Za nositele „historické paměti“ je označována rodina či kulturní společenství. Kontinuita reprodukce lidové kultury je vyjádřena v jejím předávání „, generace na generaci“, a to především „ústním podáním a napodobováním“, nepsanou tradicí, v některých případech i prostřednictvím školního a mimoškolního vzdělávání (Koncepce 2003: 3). Identita tradiční lidové kultury je pak spojována s lokační hierarchií obec-region-stát. 
Všechny zmíněné rysy lze chápat jako výčet podmínek splňujících kritéria etnické autenticity, kterými jsou kulturní homogennost, osobitost a především geografická stabilita (Handler 2001). Takto vylíčená identita lidové kultury je „historicky stabilní“. Přesto vidí dokument dost důvodů, aby s ní bylo nakládáno tak, jako by v současnosti a budoucnosti nemohla sama ,přežít“.

$[\mathrm{P}]$ o celou dobu existence tradiční lidové kultury v jejích projevech dochází k proměnám. Proměny jsou jejím prrirozeným znakem. Jde však o to, aby tento vývoj byl alespoň dokumentován a aby při těchto proměnách nedocházelo k ochuzování, a to zejména o projevy př́iznačné pro naše společenství, a tím k oslabení kulturní diverzity naší země a konec konců i kulturní diverzity v rámci evropských struktur.

(Koncepce 2003: 3)

V Koncepci je tak zaznamenán „paradox autenticity“ - lidová kultura je cenná taková jaká je, je však potřeba vyzdvihovat v ní to podstatné, co vytváŕí naši vlastní identitu. Autenticitu, spojovanou s nemanipulovaností a přirozeností, je třeba svěřit do rukou racionální a systematizující vědy a pomocí státních prostředků ji uchovat zakonzervovanou pro „další generace“. Není třeba př́liš zdůrazňovat, jak je pojem ,autenticity“ a s ním pojetí a „vzhled“ lidové kultury závislý na proměnách diskurzu národopisné vědy, stejně jako na ideologických objednávkách ze strany státu.

Autenticita by nebyla autenticitou, kdyby nemizela, respektive nezačínala mizet. Tak současně s pojmem „tradiční lidová kultura“ je vyslovováno „nebezpečí ztráty“.

Nebezpečí ztráty, kterou tradiční lidová kultura představuje, si uvědomuje světové společenství už po několik desetiletí. Uvědomuje si nutnost ochrany toho pozitivního, co lidstvo při svém vývoji vytvořilo a co se dochovalo do dnešních dnů. Státy vnímají, že např. ztráta tradičních dovedností, uměleckých forem, zvyků či rituálů a dalších hmotných i nehmotných artefaktů tradiční lidové kultury snižuje kulturní rozmanitost světa a může znamenat v některých př́ípadech i ztráty poznatků užitečných pro trvale udržitelný rozvoj, jako jsou např. některé zásady a metody tradičního zemědělství, respektu k prŕrodě apod.

(Koncepce 2003: 3)

Tento poněkud nostalgický diskurz mizení tedy není považován jen za místní projev, je fenoménem/principem celosvětovým, v použití slova „lidstvo“ téměř univerzálním. Mizí tradiční moudrost (šetrné zemědělství, respekt k přírodě), jež se může stát inspirací k obnově současných obecně lidských hodnot. Ochrana vlastní podoby „lidové kultury“ získává kontext a legitimaci na úrovni téměř kosmologické. Avšak motivace k zachování „tradičních hodnot“, a v tomto př́padě motivace k vydání Koncepce, může mít i poněkud lokálnější a konkrétnější kontext.

Jak již bylo zmíněno, symbolický modernizační displacement se uplatňuje nejen jako historické narativum - zde je kupř́kladu využit při naraci společensko-politického zlomu, který přinesl rok 1989. Znovu je vyprávěna celá historie lidstva a místa českého národa v ní, a to proto, aby mohly být rekonstituovány socialistické instituce lidové kultury, smetené ,zmatkem“ posledních třinácti let. V roce 1989 byl na 25. zasedání Generální konference UNESCO schválen dokument s názvem Doporučení k ochraně tradiční a lidové kultury, který je dosud 
jediným mezinárodně uznávaným dokumentem $\mathrm{v}$ této oblasti. Koncepce $\mathrm{v}$ něm nachází odůvodnění pro nutnost přehodnocení vztahu státu k lidové kultuře: „Situace v České republice v době politických a společenských změn po roce 1989, kdy bylo Doporučení príijato, komplikovala systematickou realizaci principů a zásad, které v něm jsou uvedeny.“

\section{Folklór - autenticita a inscenovanost tradice}

Po krátkém pokusu o analýzu současné české kulturní politiky se přesuňme na pole disciplíny folkloristiky, abychom na proměně její i jejího předmětu, folklóru, sledovali pojem autenticity, ilustrující schopnost dominantního diskurzu aktualizovat vyprávění o moderním budování národa spočívajícího $\mathrm{v}$ emancipaci ducha z prostoru tradičního řádu.

Ačkoli je předmětem zkoumání folkloristiky především tradice, nelze na ni nahlížet jako na vědu o kulturní konzervaci. Jak již bylo naznačeno výše, v analýze kulturní politiky, tradice slouží nejen k symbolizaci minulosti, ale také - svým udržováním a využíváním - k předávání hodnot dalším generacím. Folkloristika svůj předmět zkoumání neumrtvuje, neohraničuje jej zdmi muzeí a ploty skanzenů. Doklady tradice hledá v prítomném životě, a více než o jejich „herbářovou“ katalogizaci se zajímá o jejich pěstování, udržování, vytváření a př́padně i množení.

Ve folkloristice lze s jistým zjednodušením nalézt dvě obecné linie náhledu na předmět folklóru. Můžeme je nalézt například v popisu dvou názorově protichůdných táborů př́tomných v poválečném kulturním životě podaném folkloristou Václavem Frolcem:

První představoval konzervativní proud, zdůrazňující starobylost, archaičnost, „kmenovou svébytnost" lidové kultury; nerozlišoval progresivní a regresivní prvky tradice. [...] Reprezentanti progresivního proudu vycházeli z kritického hodnocení tradic lidové kultury, zavrhovali tzv. svéráz a usilovali o ústrojné a citlivé využívání a včleňování lidového umění do kontextu poválečného života.

(Frolec 1984: 262-263)

Jde od dva odlišné pohledy na totéž - zacházení s kulturním dědictvím, politikou udržování a obdělávání pole národa $\mathrm{v}$ době kulminace nacionalistického varu. Jeden ze směrů mírí do minulosti, druhý vpřed a není nutné př́liš zdůrazňovat, který z nich v následujících letech získal vrch. Přesto vítězný progresivní směr zůstává svým způsobem také konzervativní, když nerezignuje na pokus o nalezení původního a autentického. Svým způsobem předznamenává diskusi ovládající folkloristiku, ale i etnografii či antropologii, diskusi trvající od šedesátých let až do nynějška. Autenticita se přesunuje ze statického objektu hmotné i nehmotné kultury na samotného aktéra, respektive jeho projev, stále však zůstává ve hře v protikladu proti inscenovanosti a stylizaci.

Opětovně se vracející problém autenticity není vyřešen - zjištění, že „stará“ folkloristika pohltila předmět zkoumání tak, že jej vždy nutně inscenovala, že její metody byly př́liš invazivní a zároveň se „Zaprodala“ politizaci v národním uvědomování, naznačuje jen tendenci $\mathrm{k}$ další očištovací snaze, $\mathrm{k}$ pátrání po autentickém jádru. Řešení problému se pouze posouvá hlouběji do pole metodologie, aby se tak konečně i ,autenticita“ stala součástí vědeckého slovníku a odumřela $v$ něm zvěcněna a zbavena obsahu. 
Stejně jako pojem autenticity lze jen obtížně vyzávorkovat z obecně antropologické vědecké metodologické praxe, nemizí autenticita $\mathrm{z}$ předmětného zorného pole vědy, ačkoli je celá její existence psána formou nekrologu. Právě prríklad folklóru a folkloristiky ukazuje, jak autenticita, spojovaná se zaniklým typem společenského řádu, zůstává předmětem zájmu i metodologickým předpokladem moderní racionální vědy. Periodizace historie folklóru a folkloristiky se podivuhodně kryje, na pozadí obecného procesu modernizace, urbanizace a industrializace, s periodizací nástupu nacionalismu.

Historie folklóru a folkloristiky prochází nejdřive obdobím nadšeného amatérského hledání. Estetizovaný folklór vytváří kolorit tzv. národnímu uvědomování.

Od J. G. Herdera přebírali sběratelé názor, že vše, čeho lidstvo dosáhlo, je kulturní dědictví, úzce se vážící k životu konkrétního národa, a že v lidových písních se obráží duch národa. Osvícenský vztah vzdělaných vrstev k lidu můžeme zaznamenat v prvních zprávách o předvádění lidových písní a tanců už v 18. století, a to i na Moravě. Např. v roce 1755 př́i návštěvě císařovny Marie Terezie v sídle kanclére Kounice ve Slavkově u Brna se konala selská slavnost s předváděním hanáckých tanců.

(Jančář 2000: 328)

Přes postupnou institucionalizaci ve formě nejrůznějších spolků a zájmových sdružení (Sokol, škola Vesna, Vlastenecký spolek v Olomouci apod.) se folklór politizuje a stává součástí nacionalistického arzenálu. Reprezentuje lid a jeho (pra)původní kulturu, která vedle vysoké kultury národní literatury zakládá nárok na státní autonomii. $Z$ regionálních specifik se abstrahuje národní folklór - národní píseň, tanec, kroj.

V českých zemích vrcholí národně uvědomovací období ke konci 19. století všeslovanskou ideou, která se nejvýrazněji projevila v uspořádání Národopisné výstavy českoslovanské v roce 1895 v Praze. Tato akce se stala mezníkem pro formování národopisu jako vědy, ale rovněž impulzem k rozvoji hnutí, pro které se vžil př́ivlastek folklorní.

(Pavlicová a Uhlíková 1997: 6)

Vedle amatérského působení se folklór stává také součástí aktivit samotného státu a jeho politiky. Toto období lze ztotožnit s obdobím mezi léty 1918 a 1950, které Hobsbawm chápe jako „období vrcholného nacionalismu“ (Hobsbawm 2000). Český folklór nabírá na dechu se založením samostatného československého státu. Předvádění folklóru se stává běžnou součástí prezentace nejen místních zájmových, sportovních či hasičských spolků, ale také akcí zaštit’ovaných jednotlivými politickými stranami. Jako expertní orgán je v roce 1919 založen Státní ústav pro lidovou píseň, jehož prvním předsedou se stává Leoš Janáček.

Do krojů se už oblékají nejen autentičtí lidoví aktéři, ale též měštanské vrstvy, vysokoškolští studenti a jiní neautentičtí aktéři. S tím, jak se ve folklorním hnutí začínají angažovat nepůvodní nositelé, začínají se objevovat problémy s odlišením skutečného lidového umění a umění stylizovaného. Dokonce i původní aktéři přijímají za své folklórní formy, které vznikly záměrnou inscenací či historickou rekonstrukcí. „Pro veřejné uvádění programových čísel se ukázaly jako nezbytné jisté dramaturgické a režijní zásahy, jež se někdy staly dokonce určitými stereotypy pro prezentaci folklorních jevů a poznamenaly i další vývoj folklorního hnutî“ (Jančáŕ 2000: 329). 
Amatérský i státní zájem však sílí především po ukončení druhé světové války. Roku 1946 je založen Mezinárodní folklórní festival ve Strážnici. Dekretem prezidenta republiky vzniká roku 1945 Ústředí lidové kultury, organizace pečující o uchování a rozvoj oborů umělecké výroby. Brzy je vše rozhodnuto - převrat roku 1948 přináší daleko důsledněji propracovanou a manifestovanou kulturní politiku. Zakládají se místní kulturní domy, osvětové besedy a Závodní kluby ROH. Roku 1956 je ve Strážnici založen Ústav lidové kultury. Vznikají soubory lidových písní a tanců a jejich státního metodického vedení se později chápou vznikající okresní a krajská kulturní střediska (Jančáŕ 2000). V roce 1953 je založena Československá akademie věd a již existující Ústav pro lidovou píseň je do ní, současně s nově vzniklým Kabinetem pro národopis, včleněn jako Kabinet pro lidovou píseň. V roce 1954 se oba Kabinety spojují v Ústavu pro etnografii a folkloristiku ČSAV.

Šedesátá léta přinášejí v celé mezinárodní akademické obci i mimo ni sílící kritiku konceptu národa a pro označení státní populace se začíná razit pojem „obyvatelstvo“. Současně je pak kritice podrobován i koncept folklóru. V kontextu „věku technologie“, atomu a kosmických letů je foklór jednak označován za přežitek a je vyhlašována jeho „smrt“, jednak opětovně přichází snaha o očištění jeho autentické podoby. Ve stejné době, kdy se do akademického slovníku zařazuje pojem etnikum, dochází jak $\mathrm{v}$ německé, tak $\mathrm{v}$ americké folkloristické větvi ke kritice dosavadní folkloristické praxe. Hans Moser přichází s pojmem „folklorismus“, označujícím odcizené formy folklóru, vzdálené své „reálné“ prředloze, Američan Richard Dorson zas činí výpad proti „falešnému folklóru“ (fakelore). (Bendix 1997).

V témže období, roku 1958, publikuje v Literárních novinách Vladimír Mináč článek s výmluvným názvem „Tíha folkloru“ (Jančář 2000). Pojem folklorismus, nebo takzvaná „druhá existence folklóru“, stejně jako diskuse pokoušející se reflektovat vztah tohoto pojmu k folkloristice, se stává běžnou součástí obecné prezentace této disciplíny. Krize předmětu folkloristiky a jeho detradicionalizace se odráží v poněkud vágních uchopeních, jako například v definici Alana Dundese, který „lid“ chápe jako ,jakoukoli skupinu lidí“ (Bendix 1997: 198).

Zdánlivý zánik rozhraní jevišš̌/hlediště v oboru folkloristiky, lze chápat jako důsledek zděšení plynoucího z faktu, že na jevišti se nyní pohybuje př́liš mnoho lidí, kteří si navíc začínají nárokovat výklad a projev lidovosti. Folklorismus je jakýmsi lidovým útokem na experty spravovaná muzea. Zděšení z odcizení se však netrvá dlouho a je ustaveno nové př́́měří. Folklór již není jeden, folklorismu je povoleno pobývat $\mathrm{v}$ jeho blízkosti, vědomí nutnosti stylizace se stává součástí folklórní narace. Sedmdesátá a osmdesátá léta československé „,normalizace“ u folklóru oceňují obzvláště jeho „zábavnou“ funkci. V knize Prostá krása řeší Václav Frolec v roce 1984 problém autenticity/stylizovanosti folklóru takto:

Stupnice stylizace jde od výběru materiálu, zkracování folklórních textů, jednoduchých úprav lidových originálních forem $\mathrm{k}$ vyšším stylizacím; od imitací až $\mathrm{k}$ neobyčejně citlivým kompozicím, kde už folklór slouží jako zdroj inspirace vysokého umění. Snaha o umocnění uměleckého pưsobení folklóru se mění ve službu umění. Folklór přechází od své první existence ke své existenci druhé a další.

(Frolec 1984: 73)

Folklór získává skrze umění, totiž skrze jeho sociální dekontextualizaci, svou legitimitu i autenticitu. Do hry vstupuje dosavadní publikum a jeho amatérské kutilství se symboly národa. Současně s novou legitimizací předmětu pak přichází nová vlna diváckého i účastnického zájmu o folklór. V Československu sedmdesátých let opět vznikají folklórní soubory a řadí se 
vedle ostatních typů socialistické ,zájmové kulturní činnosti“. Jistou ránu pro českou folklórní scénu pak znamená zhroucení socialistického uspořádání institucí na konci 80. let.

Změny, k nimž došlo po roce 1989, se samozřejmě projevily i v této sférée kulturní činnosti. Dočasně ubylo souborů, zanikly i některé slavnosti. Byla zrušena také celá sít' státních metodických institucí. Kolektivy pracující s folklorním dědictvím si obtížně hledaly své postavení ve společnosti. Významným stimulem pro tyto aktivity se však stalo Doporučení UNESCO k ochraně tradiční a lidové kultury z roku 1989.

(Jančář 2000: 332)

Folklórní hnutí se po roce 1989, v prostředí budované občanské společnosti, transformuje z dosavadního statusu socialistické zájmové činnosti v „občanskou aktivitu“, stává se součástí neziskového sektoru. V roce 1990 vzniká Folklórní sdružení České republiky, zastřešující více než 350 souborů. Kromě toho dochází v letech 1991-1994 k institucionalizaci folklóru na úrovni regionů v rámci regionálních folklorních sdružení, jichž v současnosti působí na území republiky osmnáct (včetně folklorního sdružení armádních souborů). Opět vznikají nové festivaly, tentokrát již obohacené o aktivity „národnostních menšin“, kupříkladu Romfest, Řecké dny či Den Moravských Chorvatů (Jančář 2000: 333). Ústav pro etnografii a folkloristiku se v roce přjejmenovává na Etnologický ústav AVČR.

\section{Závěr}

V celém př́běhu folkloristiky a folklóru lze vysledovat především dva důležité rysy. Za prvé, „tradiční lidová kultura“ vždy našla dost příznivců a dokázala vyvolat dostatek zájmu, at’ už oslovila „,prostý venkovský lid“ na jedné straně a „městskou inteligenci“ či experty na straně druhé. Za druhé, folklór se vždy konstituoval v prostředí podpory a zájmu státu a jeho institucí, které mu dávají širší symbolické opodstatnění a prostor k jeho zaznamenání a projevu. Stát tu ve všech svých modernizujících se podobách představuje pozadí a zázemí - metaforicky řečeno -, vytváří divadlo a člení jej na hlediště a jeviště. Historie inscenace folklóru však není nutně založena na státní intervenci. Dochází spíše k pozoruhodnému prolínání záměrné a byrokratizované správy, institucionalizace, technologizace a svým způsobem i vyvlastňování a odcizování předmětu s angažovanou a kutilskou činností provozovanou širokým sociálním spektrem amatérů. Autenticitu nelze v tomto institucionálně-dobrovolném kontextu chápat nutně jako „falešnou hru“ či státní hegemonii. Bez státní proklamace autentizace a poskytnutí garance, bez symbolického zakotvení, by se autenticita dobrovolného folklóru či folklorismu jen těžko obešla.

I přes svou již mnohokrát předvídanou a ohlašovanou smrt tradiční lidová kultura stále přežívá. Jak je to možné? Vysvětlení se nabízí v podstatě dvojí, zjednodušeně uchopitelné jako „ahistorické“ a „historické“. První chápe lidovou kulturu jako jistý ahistorický jev, jako jednu z funkčních vrstev obecně lidské kultury, kterou z ní vyděluje její sociální inferiorita. Vychází ze zemědělství, se sepětí s půdou, a takto se svým způsobem i kotví v symbolickém univerzu - jako věčně trvající základ, vzdorující jakýmkoli, třeba vědeckým, falsifikacím a či metodologickým kritikám. Prezentuje předobraz široce rozkročeného ,prostého člověka“, srostlého se zemí, zakořeněného či zachyceného v půdě svým pracovním nástrojem. 
Druhé vysvětlení, kterého se chci přidržet, pak vychází z názoru, že těch několik století zaznamenávání a kultivace folklóru vychází především z historického - moderního - vynálezu tradice a prostého lidu (Hobsbawm 1997). Folklór či tradiční lidová kultura se zjevují ani ne tak proto, že se obávají zániku z důvodu nahrazení tradičního řádu řádem moderním, ale spíše proto, že „nový“ nastupující řád integruje „starý“ do svých útrob ve formě vznikajících narativ pojednávajících o tradiční společnosti a tradičním člověku. Ten, stejně jako „divoch“ či ,primitiv“, je dítětem moderny, ač paradoxně starým a umírajícím. Tradiční typ neodolává tlaku modernizace či ,historickému pokroku“. Všem výpadům na svou neautentičnost čelí tím, že se s každou institucionální modernizací opětovně autentizuje.

Autentický lidový člověk je specifickým představitelem kulturního Druhého. Jeho novověké ,zjevení se“ v prostoru modernizující se společnosti vyvolává jistý údiv a okouzlení - „prostý člověk“ přichází do industrializujícího se města (již bez hradeb) ve svém kroji, svléká jej a mění se v dělníka. Folklorista, obyvatel města, pro tento kroj postaví muzeum a vydá se hledat místo, odkud onen - již - dělník, který „,zapomíná na své kořeny“, přišel. Pomocí nových metod založených na principu racionality vytváŕí romantický obraz zemědělského primitiva, aby tak vystihl ducha měnící se moderní doby a oddělil starou historii od nové. Vyprávění o původu a smyslu modernizace je tak zakotveno v zániku původního a autentického. Přesun zemědělce do města, jeho vymístění, konstituuje schéma modernizačního narativa, které je z hlediska vertikální logiky displacementu nejen horizontálním posunem, nýbrž také „triumfem moci“. Je vítězstvím ducha-identity nad determinací danou prostorem, vítězstvím identity již vycházející ze ,sebe samé“, vítězstvím osvobozeného a nadřazeného ducha národa.

Kulturní politika České republiky pak může být ukázkou existence politiky, která i přes všeobecně ohlašovaný konec moderního věku čerpá ze základních modernistických schémat národní emancipace, etnicizované tradice a konceptu „tradičního řádu“ hierarchizujícího současný systém i životní svět do kategorií podřazené a nadřazené kmenové příslušnosti. A již sama reflexe estetizace pole tradice lidu, tj. rozpuštění lidového projevu v široce sdíleném a úzce chápaném umění, stejně jako jeho komodifikace prostřednictvím zvyšování jeho turistické atraktivity, neohlašuje zánik tradiční lidové kultury, nýbrž jen naznačuje završení jejího nového symbolického ukotvení.

\section{Poznámky}

1 „Rozvoj intelektuální, emocionální i morální úrovně každého občana“ (Kulturní politika 2001: 4).

2 „Propojuje Českou republiku s vnějším světem, zároveň ji však z něj i vyděluje; charakterizuje ji v porovnání s ostatními státy“ (Kulturní politika 2001: 4).

3 Tato částka tvoři 0,8 až $3 \%$ rozpočtu.

\section{Literatura}

2001. Kulturní politika. Ministerstvo kultury, Praha.

Barthes, R. 2004. Mytologie. Dokořán: Praha.

Bendix, R. 1997. In Search of Autheniticty: The Formation of Foklore Studies. University of Wisconsin Press: Madison, WI. 
Frolec, V. 1984. Prostá krása. Vyšehrad: Praha.

Handler, R. 2001. „Authenticity, Anthropology of". In: International Encyclopedia of the Social \& Behavioral Sciences. Elsevier.

Hobsbawm, E. J. 2000. Národy a nacionalismus od roku 1780. CDK: Brno.

Hobsbawm, E. , Ranger, T. 1997. The Invention of Tradition. University Press: Cambridge.

Jančář, J. 2000. Lidová kultura na Moravě. Ústav lidové kultury: Strážnice.

Jeřábek, R. 1997. Počátky národopisu na Moravě. Ústav lidové kultury: Strážnice.

Leščák, M., Sirovátka, O. 1982. Folklór a folkloristika. Smena: Bratislava.

Pavlicová, M., Uhlíková, L. 1997. Od folkloru k folklorismu. Ústav lidové kultury: Strážnice.

Taylor, CH. 2002. The Ethics of Authenticity. Harvard University Press.

Trilling, L. 1972. Sincerity and Authenticity. Harvard University Press: Cambridge MA.

Usnesení vlády České republiky ze dne 11. června 2003 č. 571 ke Koncepci účinnější péče o tradiční lidovou kulturu v České republice.

\section{Autor}

Mgr. Petr Kouřil je interním doktorandem na Katedře sociologie Fakulty sociálních studií Masarykovy univerzity v Brně. Zabývá se problematikou vztahu kulturní politiky a pojmu autenticity, se zaměřením na tradiční lidovou kulturu a kulturu minorit. Kontaktní e-mail: kouril@fss.muni.cz 